\title{
OTTOMAN MUSIC IN TRAVEL BOOKS: A PATH TO RESTRUCTURE THE FORGOTTEN OTTOMAN MUSICAL INSTRUMENTS
}

\author{
Dilek Göktürk-Cary**
}

\begin{abstract}
$\ddot{O} z$
Bu çalışmanın temel amacı, Osmanlı ve Avrupalı gezginlerin Osmanlı müziğine yapmış oldukları katkıları tarihsel anlamda gözler önüne serebilmektir. Bu makale, daha geniş çaplı bir araştırma projesinden yola çıkılarak, günümüzde unutulmuş olan Osmanlı dönemi çalgılarının o günlerdeki rolleri ve nasıl kullanıldıkları konusunu yansıtmayı amaçlamaktadır. Tarihi ve kültürel eser niteliğindeki bu çalgılar, zaman tüneli içerisinde unutularak günümüzde bizlerden talihsiz bir şekilde gizlenmişlerdir. Bu çalışmada, Osmanlı müzik yaşamı ve o döneme ait çalgılarla ilgili bilgiler, Evliya Çelebi, Guillaume Postel, Johannes Lewenklau, Cane, du Loir, d'Ohsson ve Julia Pardoe gibi gerek Osmanlı gerekse Avrupalı gezginlerin bakış açısıyla dile getirilmiştir. Bunlara ek olarak, Osmanlı minyatürleri de bu çalgıları tanıtan ve sınıflandıran açıklayıcı görsel kaynaklar olarak kullanılmaktadırlar. Bu iki kaynak arasındaki ilginç bağlantı, Türkiye'nin renkli bir mozaik gibi olan çok yönlü sanatsal mirasında yer edinmiş bu çalgıların kültürel anlamdaki önemi hususunda bir farkındalık yaratmak bağlamında atılacak bir adım olabilir.
\end{abstract}

Anahtar Sözcükler: Osmanlı çalgllarl; Seyyahlar ve Osmanlı müziği; Osmanlı sarayında eğlence; Osmanlı müzisyenleri

Abstract
The primary aim of this study is to demonstrate the important historical contribution made by written accounts of Ottoman and European travelers regarding Ottoman musical practices. This article reflects information gleaned from a larger research project that ultimately aims to illuminate the role and usage of various Ottoman-era instruments that have been forgotten in the modern era. Obscured in the vast span of time, these instruments are now historical and cultural artifacts that have been unnecessarily marginalized in our contemporary times. In this study, the musical lives of the Ottomans and their musical instruments are discussed through the perspectives of Ottoman and European travelers, including as Evliya Çelebi, Guillaume Postel, Johannes Lewenklau, Cane, du Loir, d'Ohsson and Julia Pardoe. In addition to the narratives of these travelers, Ottoman miniatures are used as revealing visual resources to identify and categorize forgotten musical instruments. The compelling connection between these two resources may become the first step towards rejuvinating awareness and understanding of the cultural significance of these instruments as colorful pieces in the mosaic of Turkey's multifaceted artistic heritage.

Keywords: Ottoman musical instruments; travelers and Ottoman music; entertainment at the Ottoman court; Ottoman musicians

\footnotetext{
** Associate Professor, Ph.D.; Independent Researcher \& Music Educator; Plantation, Florida, U.S.A. E-posta: dilekgokturk@yahoo.com
} 


\section{Dilek Göktürk-Cary}

\section{Introduction}

During the early centuries of Islam, women were particularly active in one branch of the arts: music. Although a clear statement on the act of playing music does not appear in the Qur'an when it describes social life or advises on morals, the attitude of Muslim religious scholars toward music was not at all positive. They regarded the beating of tambourines as permissible only at weddings, since such festivities should not take place in silence ${ }^{1}$. Despite the negative outlook for music in Islam (particularly when it was performed by women), from the beginning of the [Ottoman] Empire, music was an important aspect of social and cultural life. The contribution of women to Ottoman music became an integral part of community social life and became incorporated into the traditions of the society which were as strong among the people who lived in cities as it was in the court of the Sultan ${ }^{2}$. Dr. Şefika Şehvar Beşiroğlu made the following statement about the role of music in the broad expanse of the Ottoman Empire (1299-1923): "From the beginning of the [Ottoman] Empire, music was an important aspect of social and cultural life. While men received their music education in the Enderun (educational institution within the palace), the Women's Quarters (Harem) provided equally good music education for women. In addition, they were sent out to the homes of the best available instructors of the time for their musical training." ${ }^{3}$ This general observation is confirmed in the eyewitness accounts of Ottoman and European travelers who lived at various times during this intriguing period.

We have few historical records of Ottoman Court music and musical practices, particularly from the sixteenth and seventeenth centuries. As one of these few sources, in his poetry book (mesnevi) İşâretnâme, İlyas Şücâ Revânî (1475-1524) depicts the musical instruments of his time, including çeng, tanbur, ud, kanun, def, kemençe, ney, and kopuz. After Revânî, two more books, titled Saznâme (instrument book), were written by Durak Ağa (d. 1566) and Nihânî Çelebi. During the late sixteenth century, Hatip Zâkîrî Hasan Efendi (15451623) and Gâzî Giray Bora Han (1554-1607) also wrote books about the Ottoman court music ${ }^{4}$.

Seventeenth century is considered as a period of awakening in Ottoman musical life. Particularly, after the conquest of Baghdad by Sultan Murad IV from Safavid Dynasty, music became more important in the society. During this period, the Sultan brought popular and gifted musicians, including Şahkulu,

\footnotetext{
${ }^{1}$ Walther 1999

${ }^{2}$ Beşiroğlu 2006: p. 4.

${ }^{3}$ Beşiroğlu 2006: p. 4.

${ }^{4}$ Yarman 2002.
} 
Karacaoğlan (1605-1679) and Wojciech Bobowski or Ali Ufki (1610-1675). Other important names who lived in this period are Kâtip Çelebi (1609-1657) (a very famous scholar) and Evliya Çelebi (1611-1682) (a very important Ottoman traveler and musician $)^{5}$. All these Ottoman scholars and travelers wrote about music about their time; however, both European and Ottoman travelers give us, perhaps, the best description about the role and the place of music in the Ottoman Court and Ottoman society.

\section{Music and Entertainment at the Ottoman Court}

There is little knowledge about the musical life at the court; however, "with the foundation of the Ottoman Empire, artists had undertaken an active role in court life. İsmail Hakkı Uzunçarş11 states that there had been interruptions in musical life in court caused by wars and governmental disturbances during the early years of the empire and could not increase the importance of musical life in court until the reign of Murad II"6. Despite these interruptions, music still was an important part of the life at the court ${ }^{7}$.

The evidence shows that the musical performances at the Ottoman court can be traced in the sources from the fourteenth century. These performances occurred in different times and a variety of places based on the requirement of sultan $^{8}$. "In the sixteenth and seventeenth centuries, all the genres performed at the court were traditional Turkish music, namely classical, dance, folk, military and religious. Not all of them were practiced at the same level, and the settings and occasions varied"". Based on this information, it was the case that entertainment at the Ottoman Court was conducted in two ways: a) weddings or the celebration of religious days ("bayramlar"), and b) discretionary entertainment for no particular occasion. These types of entertainment were held in both inside and outside of the court. If people were invited to these activities, the type of entertainment was called as "bezm" or "meclis." Sultans could also call for private entertainment as their personal preferences (other than weddings, bayram, or throne ceremony, which was called "cülûs"), that explain the concept of the entertainment at the Ottoman court in the best way. Music and poetry were the primary activities at these meetings ${ }^{10}$. These festivities were also represented in miniatures (Pictures \#1, \#2 and \#3).

\footnotetext{
${ }^{5}$ Yarman 2002.

${ }^{6}$ Toker 2015: p. 84.

${ }^{7}$ Soydaş 2011: p. 2.

${ }^{8}$ Soydaş and Beşiroğlu 2007.

${ }^{9}$ Soydaş 2011: p. 2.

${ }^{10}$ Tarım Ertuğ 2007.
} 


\section{Dilek Göktürk-Cary}

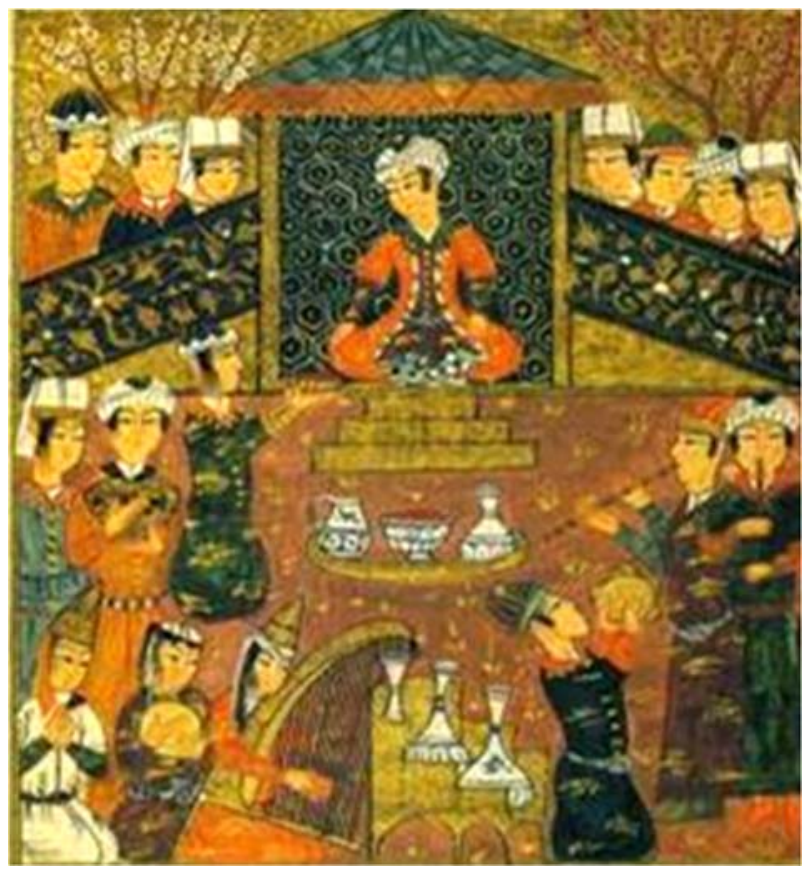

Picture 1 - male and female çeng and tambourine players, miniature from the era of Sultan Mehmet II (Fifteenth Century) ${ }^{11}$

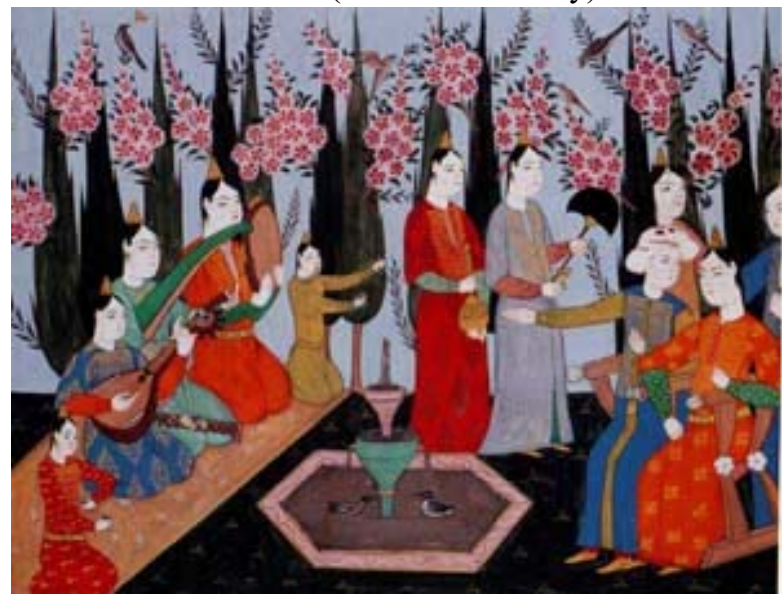

Picture 2 - entertainment / outside of the Palace with oud, çeng and tambourine players from the Album of the Sultan Ahmed I (Early Sixteenth Century) ${ }^{12}$

\footnotetext{
${ }^{11} \mathrm{http}: / /$ www.musikidergisi.net/?p=1369, retrieved on June 12, 2016. Original source: Külliyât-l Kâtibi, c. 1460 [TSMK, R. 989, Y. 93a].

$12 \mathrm{http}: / /$ www.osmanlisanati.com/p9.html, retrieved on June 12, 2016.
} 


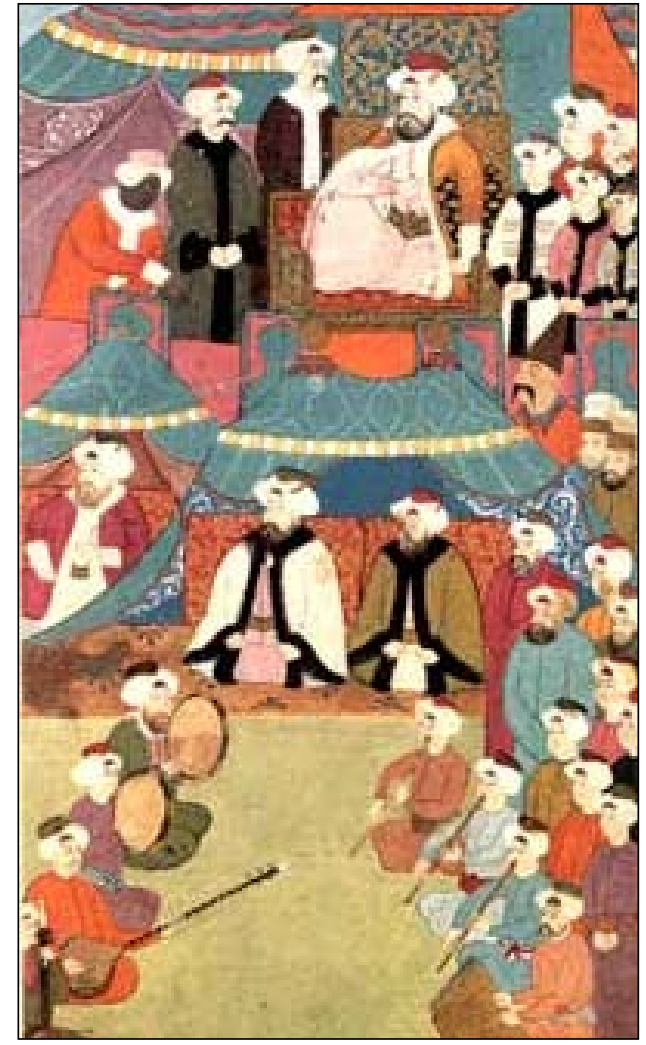

Picture 3 - The musicians at the circumcision ceremony of the sons (princes) of Sultan Ahmet III in Okmeydanı (Eighteenth Century) from Surname-i Vehbî by Levni ${ }^{13}$

During the early years of the empire, music took place at Mehterhane (military band headquarters) and Enderun Mektebi (Palace School to educate state officials). In addition to these, there were two other schools that educated students for religious purposes: Darül Kurra (school to teach reading the Koran) and Darül Huffaz (school to teach students to memorize the Koran). All of these schools educated students and future teachers in music for religious and military purposes only. Before 1826, music was not a part of the curriculum at Darül Kurra and Darül Huffaz, whic were religious institutions; however, adhan (Islamic call to worship) Koran and hymns were taught by ear through an apprenticeship approach musicians at the time. Music (secular music) was mandatory at these schools ${ }^{14}$.

\footnotetext{
${ }^{13} \mathrm{http}: / /$ www.yenidenergenekon.com/26-minyatur, retrieved on May 28, 2016.

${ }^{14}$ Kocabaş 2010.
} 


\section{Dilek Göktürk-Cary}

The amount of education in music and in poetry (means half of the education) at Enderun (Palace) schools tell us the place of music at the Ottoman Court ${ }^{15}$. The main purpose of the Enderun Schools was the Islamization of Christian children, and to prepare them to serve to the Ottoman government in bureaucratic, managerial, and Janissary military positions. Music as one of the most important activities at the Palace during the sixteenth century, the best musicians were invited to the palace for the meclis meetings ${ }^{16}$. While men received their music education in the Enderun, Harem provided equally good music education for women. "Music was one of the standard activities of [the Imperial] Harem, as they were described by Orientalist artists and some travelers" $" 17$ Women of the palace received good music education either in the Harem or from teachers outside, formed ensembles and contributed to the joyful celebrations of different occasions. By educating young women of the elite outside the palace, they also played an important role in the development of urban music in the Ottoman Empire. In Ottoman society, the participation of women in music was not limited to the palace. Well to do families, high-ranking bureaucrats and others of the educated class enjoyed musical performances in their residences ${ }^{18}$.

What we can tell after all this information is that music occupied a very important place in Ottoman society. Topkapı Palace was a virtual conservatory, where both women and men received intensive training in music. Every concubine mastered an instrument while also being instructed in singing and dancing. Meşkhane (music room) in the Palace that was used for women to receive music education resembled to a conservatory. Women could develop a musical identity through this particular training at the Harem. Moreover, some of the Harem women developed their musical abilities further and became professional players, composers, and even teachers at the Harem ${ }^{19}$. In his book, titled Ali Ufki ve Mezmurlar (1990), Cem Behar discusses a seventeenth-century wedding with Wojciech Bobowski's (Ali Ufki) description. (Ali Ufki was a Polish musician and dragoman). According to Ali Ufki, "After an hour, the friends and the other relatives of the bride began to perform various types of music. This meant for the women (including the bride) to leave the room where also men existed, and the women who left the room went to the Sultan's room

\footnotetext{
15 Tarım Ertuğ 2007.

${ }^{16}$ Erünsal 1981.

${ }^{17}$ Lewis and Micklewright 2006: p. 32.

${ }^{18}$ Beşiroğlu 2006: p. 4.

${ }^{19}$ Beşiroğlu 2006.
} 
to congratulate him. Afterwords, the women were entertained with music until dawn. $" 20$

Turkish influence on the West was particularly strong during the Classical Period, which lasted from the sixteenth century until the middle of the eighteenth century. However, due to military defeats and loss of lands for the Ottomans, Turkish influence on the West reversed, and the Westernization Period in the Ottoman State began from the middle of the eighteenth century. During this era, Western artistic traditions and trends took a very important place, particularly at the Ottoman court ${ }^{21}$ since "the Ottoman Empire was no longer the great, powerful, cohesive entity of the Golden Era of the fifteenth and sixteenth centuries. Something had to be done to save it from the persistent threat of the European powers and from internal disintegration. In 1792 the new sultan sought advice from eminent Ottoman on how to meet the European challenge, and how to save the empire. Some of these men suggested reforms, thus ushering in the period of westernization or modernization." 22 As a result, the high period for the musical training for the Harem women [also] lasted until 1754, when Sultan Mahmud I died. After the death of the Sultan, the music of the Harem lost its speed, and starting from the seventeenth century the residents of the Harem moved outside of the sultan's palace to other palaces of the sultan and highly ranked men ${ }^{23}$.

By the nineteenth century, these effects reached at its peak. This period witnessed major changes both in the East and in the West, regarding new approaches in fine arts that occurred as an opposition to the Classical Period. These reforms were particularly developed in the areas of fine arts, such as in literature, art, architecture and music ${ }^{24}$.

\section{Ottoman-Era Musical Instruments}

The writings of travelers such as Evliya Çelebi and Guillaume Postel remain invaluable resources that supplement the fragmented historical record of the Ottoman Empire. Specifically regarding musical practices, the written accounts of Ottoman travelers continue to play important roles in revealing the nature, instrumentation and performance practices of Ottoman-era music. Many of these musical compositions provided vital aesthetic and religious outlets for citizens of the Empire. Since musical life also reflects the overall cultural life,

\footnotetext{
${ }^{20}$ Behar 1990: 75.

${ }^{21}$ Aritan 1993.

22 Turan 1997: p. 8.

${ }^{23}$ Erguner 1993.

24 Özalp 2000; Horata 2002.
} 
these works often expose intriguing first-hand accounts of the life perspectives of Ottoman citizens, and they detail how many people lived during this period. Readers also receive insight into how social and cultural changes affect evolving musical practices. These documents, for example, provide compelling information about why some musical instruments lost their popularity in time, and they shed light on the causes of their decline in usage.

Some of the musical instruments that were used during Ottoman Empire time can be listed as follows: santur (zither), çeng (Ottoman harp), çögür (similar to today's short-necked bağlama) (these three instruments are represented in Picture \#4), miskal or musikar (panflute), nefir (horn), rebab (bowed instrument) (these three instruments are represented in Picture \#5), daire, çalpara (finger cymbals) (these two instruments are represented in Picture \#6), bozuk, sine, and mazhar or bendir (these three instruments are represented in Picture \#7). Although some of these instruments completely vanished in time, some of them are still in use.

Santur (zither): "It is of Jewish origin and is still played by the Jews in the Orient." ${ }^{25}$ Evliya Çelebi mentioned this string instrument in his Seyahatnâme. Santur had metal strings on a wooden body and played with wooden felt sticks or plectrums. Santur is still a popular instrument, particularly in Iran and Turkey. ${ }^{26}$ (Picture \#4; on the left).

Çeng (Ottoman harp): The çeng - the Ottoman harp - was widely used in court music_from the fifteenth to the eighteenth century, and it was especially popular in the Harem ${ }^{27}$. According to Evliya Çelebi, çeng was "invented by Pythagoras to solace Solomon. It is a great instrument in the form of an elephant's trunk. It has forty strings and its sound is astonishing. There are but few who play it because it is a difficult instrument." 28 (Picture \#4; in the center).

Çögür (short-necked bağlama): This string instrument looked like today's short-necked bağlama or saz and was very popular among Janissaries. One of the earliest mentions about çögür was in Evliya Çelebi's Seyahatname as an instrument with five strings, wooden body and 26 frets. During the seventeenth century, çöğür was described as a string instrument having a large and round body and was played with a plectrum. This instrument vanished during the nineteenth century and later during 1800 s, it became similar to today's short-necked bağlama. ${ }^{29}$ (Picture \#4; on the right).

\footnotetext{
${ }^{25}$ Farmer 1936: p. 32.

${ }^{26}$ Yarman 2002.

${ }^{27}$ Soydaş 2011: p. 6.

${ }^{28}$ Farmer 1936: p. 30.

${ }^{29}$ Sanal 1993: p. 377-379.
} 

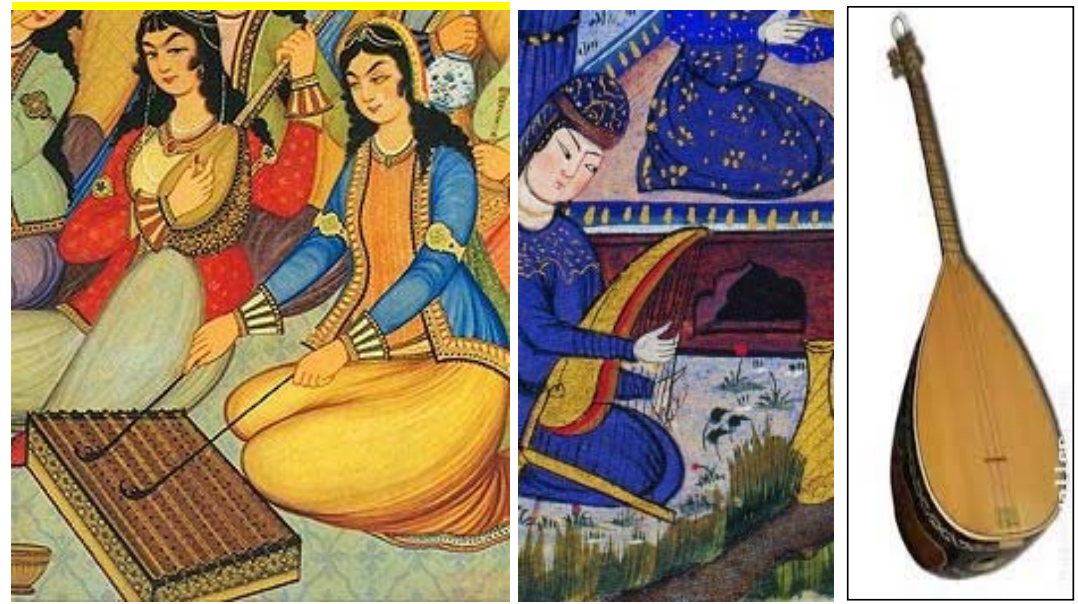

Picture 4 - santur (zither) ${ }^{30}$, çeng (Ottoman harp) ${ }^{31}$ and çöğ̈̈r (short-necked bağlama) ${ }^{32}$
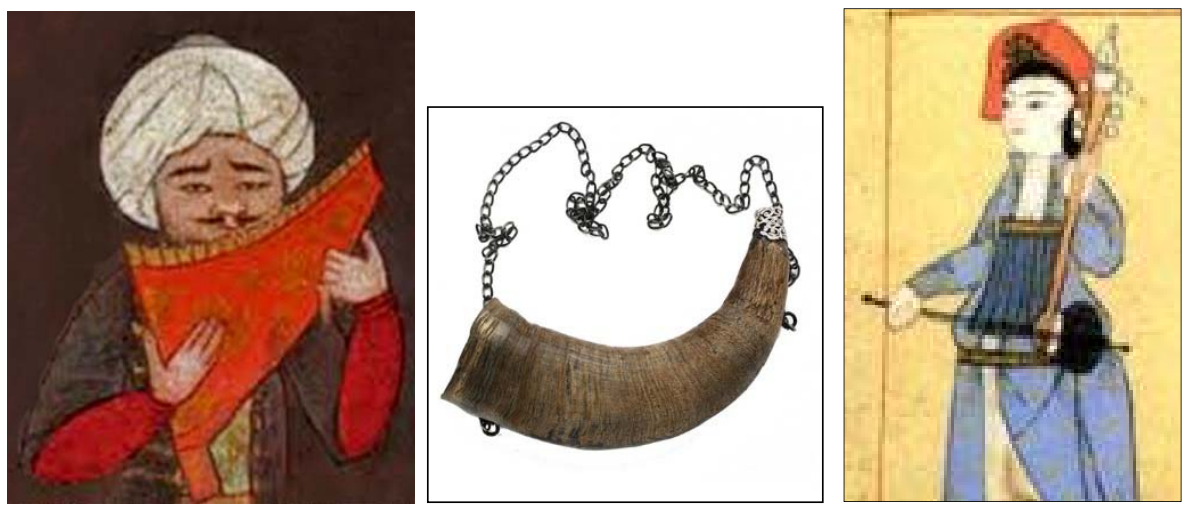

Picture \# 5-miskal or musikar (panflute) ${ }^{33}$, nefir (horn) ${ }^{34}$ and rebab (bowed instrument) ${ }^{35}$

Miskal or musikar (panflute): Miskal is called as Ottoman panflute. There were two different types of miskal based on their sizes (battal or kaba miskal:

${ }^{30} \mathrm{https} / /$ tr.wikipedia.org/wiki/Santur, retrieved on May 28, 2016. Original source: Hasht-Behesht Palace, Isfahan, Iran from 1669.

${ }^{31} \mathrm{http}$ :/www.sirinpancaroglu.com/projeler/ceng/, retrieved on May 28, 2016. Original source: from Behram Gur's Entertainment, Hamse-i Hüsrev Dehlevî, 1498 [TSMK, H. 799, y. 186b].

${ }^{32} \mathrm{http}: / /$ www.dersimiz.com/bilgibankasi/COGUR-NEDIR-HAKKINDA-BILGI-1920.html, retrieved on May 28, 2016.

${ }^{33} \mathrm{http}$ ://instrumundo.blogspot.com.tr/2013 0113 archive.html, retrieved on May 28, 2016.

${ }^{34} \mathrm{http}: / /$ www.necatikorkmaz.com/nef\%C4\%B0r.htm, retrieved on May 28, 2016.

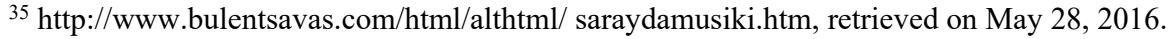




\section{Dilek Göktürk-Cary}

big miskal; and girift or cura miskal: small miskal) ${ }^{36}$. It existed at the court from the sixteenth century until the late nineteenth century ${ }^{37}$. Miskal was an instrument that had been used in the Balkan musical genres for many centuries. It is supposed that it was developed from the panpipe of the antiquity. It is of greater possibility that this musical instrument came to İstanbul from the Balkans. Miskal was used in İstanbul both in court music and urban light music. It was so popular as an instrument that in the sixteenth century one could see miskal players on the streets in İstanbul ${ }^{38}$ (Picture 5; on the left).

Nefir (horn): Nefir was a horn, which was used as the indicator of the attack for the army in a war. It did not have any holes on the body. Nefir has been forgotten for about two centuries in Turkish music ${ }^{39}$ (Picture 5; in the center).

Rebab (bowed instrument): Rebab, a bowed instrument with three strings, is believed to date back to the times of King Solomon. Kemençe is considered as an instrument resembling rebab in today's Turkey ${ }^{40}$. Rebap was still a favourite instrument in the first half of the eighteenth century, but it was replaced by the sine kemanı (violin) and the Western violin in the second half of the same century ${ }^{41}$ (Picture $\# 5$; on the right).

Daire: "The principal percussion instrument of Ottoman classical music was the daire - a tambourine with five cymbals - and it was used throughout [the] court history"42 (Picture \#6; on the left).

Çalpara (finger cymbals): In his Seyahatnâme, Evliya Çelebi mentioned these four-piece finger cymbals that are similar to castanets in the West. Çalpara, a rhythm intrument, could be made of wood or metal and were played by dancers through the use of their fingers ${ }^{43}$. It was the essential instrument of the dancers; and evidence denotes that it was played at the court from the sixteenth century on, although it is also likely to have been used before then ${ }^{44}$ (Picture \#6; on the right).

Bozuk: Bozuk means not functioning or modified. ${ }^{45}$ The name comes from a particular re-entrant tuning called bozuk düzen. A re-entrant tuning is a tuning of a stringed instrument where the strings (or more properly the courses on

\footnotetext{
${ }^{36}$ Yarman 2002.

${ }^{37}$ Soydaş 2011: p. 6 .

${ }^{38}$ Aksoy http://www.goldenhorn.com/display.php4?content=library\&page=golden_aksoy02.html.

${ }^{39}$ Yener 2012.

${ }^{40}$ Yarman 2002.

${ }^{41}$ Aksoy http://www.goldenhorn.com/display.php4?content=library\&page=golden_aksoy02.html.

${ }^{42}$ Soydaş 2011: p. 4.

${ }^{43}$ Yarman 2002.

${ }^{44}$ Soydaş 2011: p. 7.

${ }^{45}$ Hood 2011
} 
coursed instruments) are not ordered from the lowest pitch to the highest pitch (or vice versa). The Greek instrument called the bouzouki is derived from the bozuk $^{46}$ (Picture \#7; on the left).
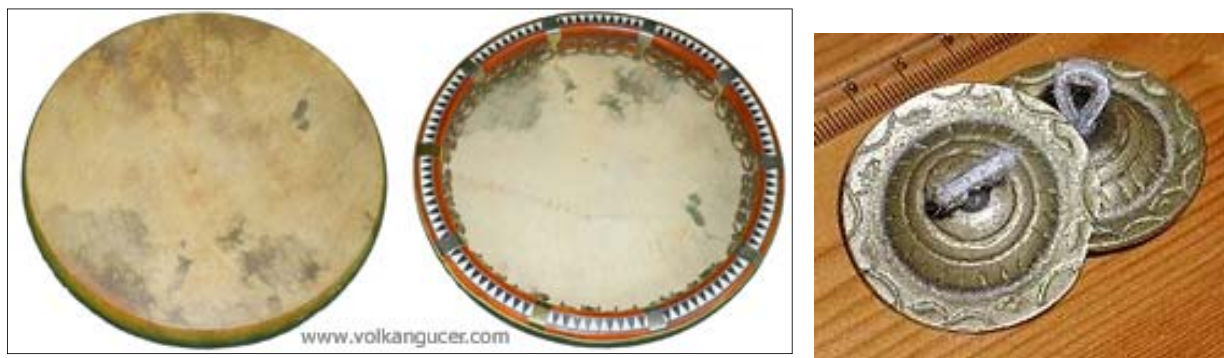

Picture 6 - daire $e^{47}$ and çalpara (finger cymbals) ${ }^{48}$

Sine: "The sine keman is the European viola d'amore that came to İstanbul in the second half of the 18th century and it was adopted in Turkish music in a short time. It also entered court music in the same period and undertook the position of the kemânçe (rebab) until the second half of the 19th century. The keman or the European violin also started to be used in Turkish music and entered the court in the 18th century and in the following century it became the leading bowed instrument" ${ }^{\prime 49}$ (Picture 7; in the center).

Mazhar or bendir: Mazhar was a tambourine without rattles ${ }^{50}$ (Picture 7; on the right).

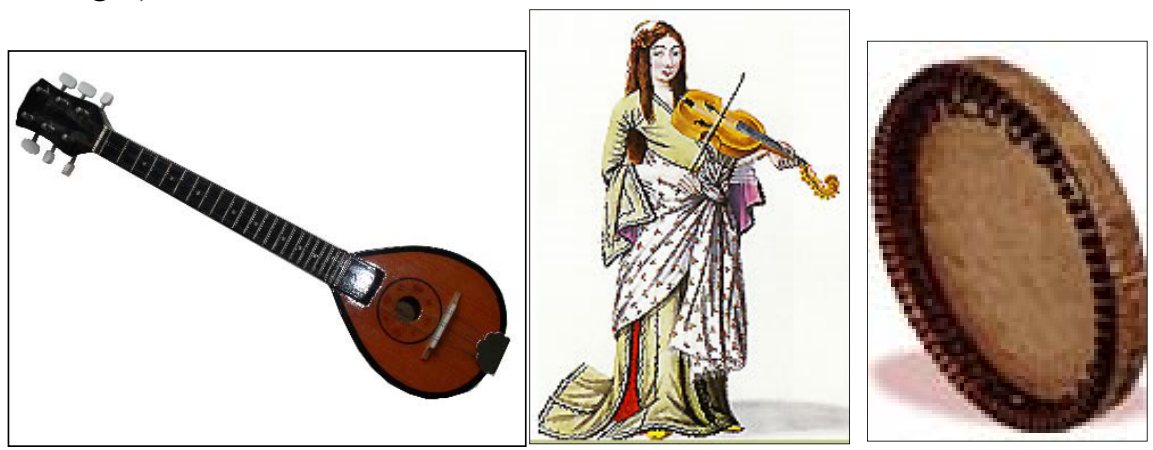

Picture $7-$ bozuk $^{51}$, sine ${ }^{52}$, and mazhar or bendir ${ }^{53}$

\footnotetext{
${ }^{46} \mathrm{http}: / /$ www.sarantismantzourakis.hu/abuzuki_eng.html.

${ }^{47} \mathrm{http}: / /$ www.volkangucer.com/winds2.html, retrieved on May 28, 2016.

${ }^{48} \mathrm{http}$ ://www.forumalew.org/soru-lar-ve-cevap-lar/362884-vurmali-cagilardan-calpararesmi.html, retrieved on May 28, 2016.

${ }^{49}$ Soydaş and Beşiroğlu 2007: p. 4.

${ }^{50}$ Yarman 2002.
} 


\section{Music in Ottoman Society from the Eyes of Travelers ${ }^{54}$}

"The first encounter between the West and Turks dates back to crusaders' time. Although this relationship continued for centuries with some intervals, there was not enough written records about Turks, except travel books by travelers." ${ }^{55}$ Furthermore, a bigger problem is the lack of written documents by Ottomans about their arts and culture ${ }^{56}$; consequently, the researchers in the area mainly rely on the travel books by European (and some Turkish) travelers regarding Ottoman/Turkish culture and life style. Below, representative travelers and their writings are presented, with particular focus on the information about Ottoman music.

One of the oldest travel books that including engravings and lithography about the daily life of Ottomans was written by Guillame Postel (1510-1581) (Picture \#8). Lived in İstanbul during 1530s, Postel was first sent as an ambassador by the French King François I to the Ottoman land in 1535 and later re-visited in 1549. The main purpose for him to be sent to Ottoman Empire was to collect books and writings for the King's library in France. He wrote his travel book titled De la Republique des Turcs in 1560. Postel's book consists of three sections and each section includes details about the daily life, culture, traditions and the historical background of the Empire ${ }^{57}$. The section that includes the music has pictures of çeng and dancing girls. In this part of his book, Postel described how the instrument was played between two legs through his drawings ${ }^{58}$ and mentioned about a female team of çeng players that he watched in İstanbul ${ }^{59}$.

${ }^{51} \mathrm{https} / / /$ commons.wikimedia.org/wiki/File:GreekBaglama1.jpg, retrieved on May 28, 2016.

$52 \mathrm{http} / /$ www.turkishmusicportal.org/instrument.php?id=12\&cat=1\&lang2=en, retrieved on May $28,2016$.

${ }^{53} \mathrm{http}: / /$ www.tumata.com/ContentDetail.aspx?cid=37, retrieved on May 28, 2016.

${ }^{54}$ For more information about European travelers in the Ottoman land and their perspectives on Turkish music and culture, Bülent Aksoy's book, which is titled Avrupalı Gezginlerin Gözüyle Osmanlılarda Musıki, and Feza Tansuğ's review on the same book "Bülent Aksoy'un Avrupalı Gezginlerin Gözüyle Osmanlılarda Musiki'si Üzerine" from the Tarih ve Toplum journal are recommended.

${ }^{55}$ Aksoy 2003: p. 27.

${ }^{56}$ Aksoy 2003.

${ }^{57}$ Arıkan 1984.

${ }^{58}$ Beşiroğlu and Koçhan 2007: p. 137.

${ }^{59}$ Aksoy http://www.goldenhorn.com/display.php4?content=library\&page=golden_aksoy02.html. 


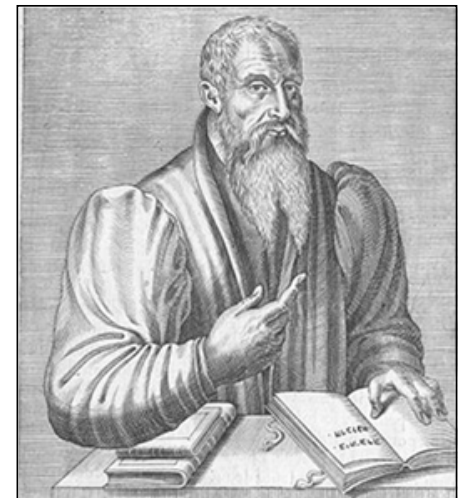

Picture 8 - Guillaume Postel (1510-1581)

The Danish painter Melchior Lorichs (1526/27-1583) (Picture 9), who visited İstanbul between 1555-1560, made engravings representing Gypsy women playing the çeng. One of his paintings shows two women playing the çeng and another woman accompanying them with the tambourine ${ }^{61}$. Another traveler, Cane, who was a traveler from the sixteenth century, mentioned the musical life in İstanbul and Ottoman women in his memoirs. In his book, Cane mentioned Turkish women as follows: "Turkish women have dark eyes and dye their eyebrows. Their hair is black, and if it is not they dye it to black. Subtle, tasteful and clever Turkish women sing, play musical instruments, and when they play they look very hearty that the audience can get drunk on love for them." 62

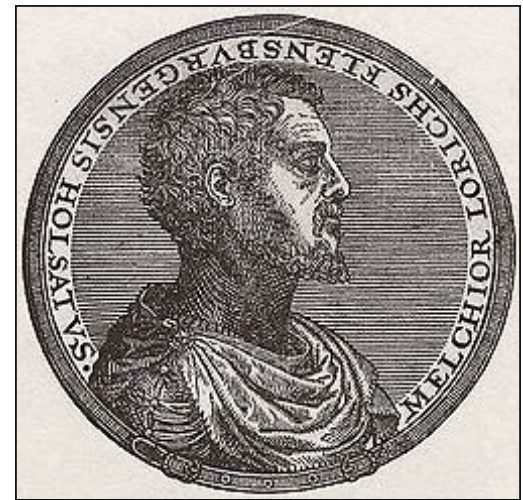

Picture 9 - Melchior Lorichs $(1526 / 27-1583)^{63}$

\footnotetext{
${ }^{60} \mathrm{https} / / /$ en.wikipedia.org/wiki/Guillaume_Postel, retrieved on May 30, 2016.

${ }^{61}$ Aksoy http://www.goldenhorn.com/display.php4?content=library\&page=golden_aksoy02.html.

${ }^{62}$ Beşiroğlu 2002: p. 457.

${ }^{63} \mathrm{http}: / /$ www.wikiwand.com/de/Melchior_Lorck, retrieved on May 30, 2016.
} 


\section{Dilek Göktürk-Cary}

Johannes Lewenklau (1541-1594), visited İstanbul in 1580s and wrote a book in 1586. For his book, Lewenklau asked a street painter to draw each specific profession that Ottoman people did. In these drawings women were portrayed as musicians along with men. Sieur Jean Antoine du Loir was another traveler who was a French merchant who came to İstanbul in 1639 with the French ambassador Jean de la Haye and stayed for seventeen months. During this period of time, he wrote letters to his friends in France describing life and events in the Ottoman land. These letters were later published as a book (Les Voyages du Sieur du Loir) that includes historical facts as Baghdad expedition in 1639, the death of Sultan Murad IV, and incidents during Sultan İbrahim's reign. Du Loir further mentioned the historical parts and districts of İstanbul, the Ottoman Palace, and cultural facts, as religion, life style and ethics of the Turkish society ${ }^{64}$. The memories of du Loir from the early seventeenth century also described the musical life in Ottoman society. One of his recordings indicates that Turks listened to music when they ate dinner. He also had witnessed that when male and then female musicians performed after the dinner, women audience had to listen to the music behind the curtains ${ }^{65}$. Du Loir stated that the word çengi derived from çeng and that meaning of the çengi was both a çeng player and dancer who danced to the çeng music. This etymological information refers to the relation between the çeng and Çingene (Gypsy) because all the çengis were Gypsy women. While çengis played the çeng, other women musicians played rebab and daire. In the middle, dancing women also played çalpara ${ }^{66}$.

Evliya Çelebi (1611-1682) was born in İstanbul, travelled the length and breadth of the Ottoman Empire as well as some neighboring regions, and died in Egypt after writing his huge Seyahatnâme (Book of Travels) and he talks widely about the musical life in İstanbul in his Seyahatnâme ${ }^{67}$. "He had been taught music and singing by one of the best masters of the day, the Khalwati dervish Umar Gulshani, who lived to the great age of 140 years, himself having been taught by the eminent shaikh Ibrahim Gulshani (d. 1533-4) of Cairo. After two years' service as a musdhib, Ewliya began his travels which have made him famous." ${ }^{\text {68 }}$ According to him, 4000 musicians and hundreds of singers and luthiers existed in İstanbul during during his time. Evliya Çelebi also mentioned about 76 different musical instruments that were actively performed with and noted that çögür was an instrument mostly played among janissaries.

\footnotetext{
${ }^{64}$ Aksoy http://www.goldenhorn.com/display.php4?content=library\&page=golden_aksoy02.html.

${ }^{65}$ Beşiroğlu 2002.

${ }^{66}$ Aksoy http://www.goldenhorn.com/display.php4?content=library\&page=golden_aksoy02.html.

${ }^{67}$ Çelik Şavk 2011.

${ }^{68}$ Farmer 1936: p. 2.
} 
Furthermore, he pointed out that 12 janissary minstrels who also played çöğür had attended to the fest which was in honour of the İpşir Paşa's promotion to grand viziership. These findings indicate that there were a significant number of Minstrels among the janissaries ${ }^{69}$. "The Turkish text of certain extracts from the first part of his travels was published at Constantinople in 1843 under the title of MuntaJchabdti Ewliya Chelebi. Von Hammer issued part of the travels in English as a Narrative of Travels in Europe, Asia, and Africa in the Seventeenth Century by Evliya Efendi (London, 1846-1850).2 It contains two sections on instruments of music, as well as frequent references to them elsewhere." ${ }^{.70}$

Ignatius Mouradgea d'Ohsson (1740-1807) (Picture \#10), who lived in İstanbul during the eighteenth century mentioned about the entertainment in his books as follows:

- Tableau Historique de l'Orient. (2 volumes)

- Tableau Général de l'Empire Othoman (7 volumes)

- L'Histoire de la Maison Ottomane (from Osman I till 1758)

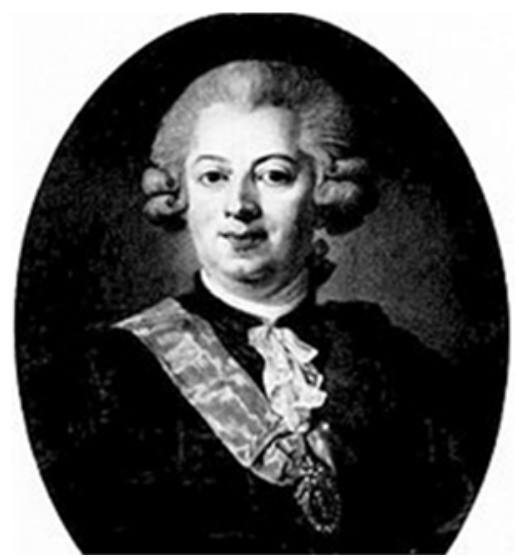

Picture \#10 - Ignatius Mouradgea d'Ohsson (1740-1807) $)^{71}$

D'Ohsson gave an example on female musicians as follows: "Sources include the entertainment of women the most. The places they have entertainment are Kâğgthane and Küçüksu, where çengis dance and sing with the accompaniment of the music that was played by çeng, daire and zil players." ${ }^{.72}$

\footnotetext{
${ }^{69}$ Yarman 2002.

${ }^{70}$ Farmer 1936: p. 2.

$71 \mathrm{https} / / /$ www.geni.com/people/Ignatius-Mouradgea-d-Ohsson/6000000017732683184, retrieved on June 2, 2016.

${ }^{72}$ Beşiroğlu 2002.
} 
Julia Pardoe (1806-1862) (Picture \#11), who was an English poet, novelist, historian and traveler, also visited the Ottoman land during the early nineteenth century. The three books she wrote (The City of the Sultan, Romance of the Harem and The Beauties of the Bosphorus, which is an illustrated account of İstanbul) describe the musical life of Ottoman Empire from a woman's perspective. She has similar descriptions of female musicians as d'Ohsson ${ }^{73}$.

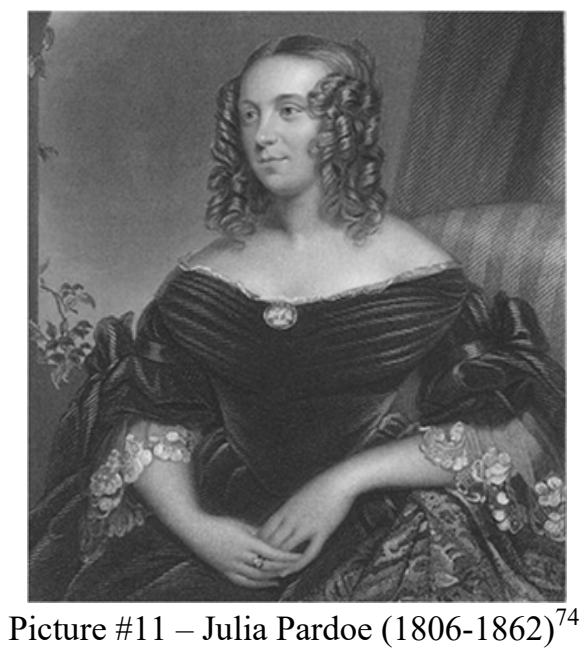

\section{Conclusion}

According to Henry George Farmer (1882-1965), a British musicologist, some Ottoman musical instruments fell into desuetude shortly after Evliya Çelebi's day ${ }^{75}$. Among these instruments the çeng, particularly, has a history of popularity followed by relative oblivion due to sociological and technical reasons. One of these reasons was because the Enderun schools lost their importance during the era of Sultan Mahmud II (1808-1839), the relationship between the Palace and Turkish music weakened. Also, the growing Westernization movement during the nineteenth century led to the use of European musical instruments, and most of the Ottoman instruments have unfortunately not come down to our age, being lost in the mists of time. Indeed, as an example, once-popular instrument the çeng has vanished completely, not a single example being left even in the museums.

\footnotetext{
${ }^{73}$ Beşiroğlu 2002.

${ }^{74} \mathrm{https} / / /$ tr.wikipedia.org/wiki/Julia_Pardoe, retrieved on June 2, 2016.

${ }^{75}$ Farmer 1936: p. 31.
} 
This occurence leaves an unfortunate vacancy in the colorful cultural life of the Ottoman Empire. This historial void provides an opportunity and perhaps even an aesthetic imperative in our contemporary period to renconsruct the past through raising awareness of these forgotten musical treasures. Most likely, the best way to achieve this goal would be bringing these instruments back to life through the use of technology. A technological museum of forgotten Ottoman musical instruments would be a great contribution to Turkey's culture. Moreover, "musical training of these instruments should be provided at conservatories in Turkey." "76 As Yarman suggests to create a National Culture of Music through the collaboration of all musicians in Turkey, regardless the type of music (European or Turkish music), creating such musical culture should also be our main goal, so that we can carry this precious heritage on to next generations successfuly.

${ }^{76}$ Yarman 2002: p. 23. 


\section{References}

Aritan 1993

Aksoy 2003

Aksoy

Arıkan 1984

Behar 1990

Beşiroğlu 2002

Beşiroğlu 2006

Beşiroğlu and Koçhan 2007

Şehvar Şefika Beşiroğlu - Günay Koçhan, “Çeng: Bir Çalgının Toplumsal Cinsiyet Üzerinden Kadın Simgesi Olarak Kuzey Hint, Timur ve Osmanlı Saraylarındaki Görsel Malzemeler Üzerinden Değerlendirilmesi”, ICANAS Conference Proceedings, http://www.ayk.gov.tr/wp-content/uploads/2015/ 01/BE\%C5\%9E\%C4\%B0RO\%C4\%9ELU-\%C5\%9E.-\%C5\%9 Eehvar-KO\%C3\%87HAN-G\%C3\%BCnay-\%C3\%87ENG-B $\% \mathrm{C} 4 \%$ B0R- $\%$ C3\%87ALGININ-TOPLUMSAL-C $\% \mathrm{C} 4 \% \mathrm{~B} 0 \mathrm{~N}$ S\%C4\%B0YET-\%C3\%9CZER \%C4\%B0NDEN-KADIN-S\%C 4\%B0MGES\%C4\%B0-OLARAK-KUZEY-H $\%$ C4\%B0NT-T $\% \mathrm{C} 4 \% \mathrm{~B} 0 \mathrm{MUR}-\mathrm{VE}-\mathrm{OSMANLI}-\mathrm{SARAYLARINDAK} \% \mathrm{C} 4 \%$ B0-G\%C3\%96RSEL-MALZEMELER-\%C3\%9CZER\%C4\% B0NDEN-DE\%C4\%9EERLEND\%C4\%B0R\%C4\%B0LMES $\% \mathrm{C} 4 \% \mathrm{~B} 0 . \mathrm{pdf}$, retrieved on June 1, 2015.

Çelik Şavk 2011 Ülkü Çelik Şavk, Sorularla Evliya Çelebi: Insanlık Tarihine Yön Veren 20 Kişiden Biri, Hacettepe Üniversitesi Basımevi, Ankara.

Erguner 1993

Erünsal 1981
Süleyman Erguner, Chants du Harem: Ensemble des femmes d'Istanbul [Series: Musique ottomane = Ottoman Music], Al Sur: ALCD 127, CD.

İsmail Erünsal, "Türk Edebiyatı Tarihinin Arşiv Kaynakları I: II. Bayezid Devrine Ait Bir İnamat Defteri”, Tarih Enstitüsü Dergisi, volume 10, issue 11, pp. 303-342, 
Ottoman Music In Travel Books: A Path to Restructure the Forgotten Ottoman Musical Instruments

Farmer 1936 Henry George Farmer, "Turkish Instruments of Music in the Seventeenth Century", Journal of the Royal Asiatic Society of Great Britain and Ireland, volume 1, pp. 1-43.

Hood 2011 John Hood, "A History of the Bouzouki and its Music", CLIO, https://cliojournal.wikispaces.com/A+History+of+the+Bouzou ki+and+its+Music, retrieved on June 17, 2017.

Horata 2002 Osman Horata, "Lâle Devrinden Tanzimat'a Türk Edebiyatı", Türkler, volume 3, pp. 893-906.

Kocabaş 2010 Ayfer Kocabaş, "Müzik Eğitiminin Çoklu Zeka Alanlarına Etkisi ve Köy Enstitüleri”, Yeniden İmece Dergisi, volume 4, pp. 53-57, www.muzikegitimcileri.net, retrieved on June 17, 2017.

Lewis and Micklewright 2006

Reina Lewis - Nancy Micklewright, eds. Gender, Modernity and Liberty, IB Tauris \& Ltd, New York.

Özalp $2000 \quad$ Nazmi Özalp, Türk Mûsikîsi Tarihi, MEB Yayınları, İstanbul.

Sanal 1993 Haydar Sanal, "Çögüru”, İslam Ansiklopedisi, volume 8, pp. 377-379.

Soydaş 2011 Emin Soydaş, "Musical Performance at the Ottoman Court In the Sixteenth and Seventeenth Centuries", PERFORMA '11 Proceedings and Abstracts Book, http://performa.web.ua.pt/pd f/actas2011/EminSoydas.pdf, retrieved on May 27, 2015.

Soydaş and Beşiroğlu 2007

Emin Soydaş - Şefika Şehvar Beşiroğlu, "Osmanlı Saray Müziğinde Yaylı Çalgılar”, ITÜ̈ Dergisi Sosyal Bilimler Serisi, volume 4, issue 1, pp. 3-12,

Tansuğ 1995

Feza Tansuğ, "Bülent Aksoy'un Avrupalı Gezginlerin Gözüyle Osmanlılarda Musiki'si Üzerine", Tarih ve Toplum, volume 24, p. 144.

Tarım Ertuğ 2007 Zeynep Tarım Ertuğ, "16. Yüzyılda Osmanlı Sarayında Eğlence ve Meclis", Uluslararası İnsan Bilimleri Dergisi, volume 4 , issue 1 , pp. 1-15.

“The Bouzouki" http://www.sarantismantzourakis.hu/abuzuki_eng.html, retrieved on May 28, 2015.

Toker 2015 Hikmet Toker, "Courtier Minstrels", Rast: Uluslararası Müzikoloji Dergisi, volume 3, issue 1, pp. 80-100,

Turan 1997 Selahattin Turan, "John Dewey's Report of 1924 and His Recommendations on the Turkish Educational System Revisited", American Educational Research Association (AERA), http://files.eric.ed.gov/fulltext/ED416159.pdf, retrieved on August 6, 2015. 


\section{Dilek Göktürk-Cary}

Walther 1999

Yarman 2002

Yener 2012
Wiebke Walther, Women In Islam: From Medieval to Modern Times, Markus Wiener, Princeton.

Ozan Yarman, "16. ve 17. Yüzyıllarda Türk Çalgıları", http://www.ozanyarman.com/files/musikicalgilar.pdf, retrieved on June 18, 2015.

Serhat Yener, "Osmanlı Dönemi Minyatürlerinde Enstrüman Figürleri Üzerine Bir İnceleme", Atatürk Üniversitesi Sosyal Bilimler Enstitüsü Dergisi, volume 16, issue 1, pp. 169-186, 